\title{
Use of Big Book Learning Media to Improve Students' Beginning Reading Skills in Primary Schools
}

\author{
Riga Zahara Nurani ${ }^{{ }_{1}}$, Hatma Heris Mahendra²
1,2 Primary School Teacher Education, Universitas Perjuangan, Tasikmalaya, Indonesia $\bowtie$ rigazn@gmail.com

\begin{abstract}
This study is motivated by the fact that there are still many lower grade students who have not been able to read fluently. Big book learning media can be used by teachers to teach beginning reading to lower grade students. The purpose of this study is to describe the use of big book learning media to improve beginning reading skills. The study employed a qualitative descriptive method. The subjects were second-grade primary school students who were still unable to read. The research was conducted in one of the primary schools in Tasikmalaya City. The results revealed that students were more enthusiastic in learning to read using big book learning media, which could be seen from an increase in students' reading skills in each meeting. By using big book learning media, in addition to learning to read through a series of letters, students were able to learn to read through images followed by the writing. Therefore, big book learning media can be used to improve students' reading skills.
\end{abstract}

Keywords: Beginning, big book, media, reading skills, students

How to Cite: APA style. Nurani, R. Z. \& Mahendra, H. H. (2019). Use of Big Book Learning Media to Improve Students' Beginning Reading Skills in Primary Schools. Mimbar Sekolah Dasar, 6(3), 330-340. DOI: 10.17509/mimbar-sd.v6i3.22893.

INTRODUCTION Reading is one of the language skills that must be possessed by individuals, including primary school students. Reading skills are divided into beginning reading skills and further reading skills (Rahim, 2008). Beginning reading skills are associated with first-grade and secondgrade primary school students. While, further reading skills are taught starting from third-grade. The differences of beginning and further reading skills lies in the teaching material.

In the beginning reading, the main focus of learning is the introduction of written symbols and how to pronounce them in oral form. Moreover, there are two stages in the beginning reading, namely pre-reading and reading stages. In the pre-reading stage, students are taught how to sit properly during the reading process, how to open books, how to hold books, and how to look at book. While in the process of reading, students are taught how to recite symbols or write on a book clearly, and how to understand the content or meaning of reading.

Reading is a process carried out by the reader to get the message conveyed by the writer in the forms of words or writings (Tarigan, 2008; Abidin, 2010). Reading is an interactive process in which the reader constructs a meaningful representation of a text using effective reading strategies (Gilakjani, 2016). To understand a sign of writing, planned learning activities are required. However, reading activities are 
Riga Zahara Nurani \& Hatma Heris Mahendra, Use Of Big Book Learning Media To Improve Students'...

usually only learned by individuals when they enter school. This is different from listening activities that can be learned by individuals naturally before they enter school. Basically, language learning in elementary schools can improve cognitive abilities and student leaning achievement (Stewart, 2005; Amutha \& Philomina, 2015).

Learning to read is divided into two stages, namely beginning reading and further reading. The purpose of beginning reading is that students can recognize letters, and read them into simple words and sentences correctly and fluently. While the purpose of further reading is that students can understand the meaning contained in writing or reading. Beginning reading is applied in first-grade and second-grade of primary school, while further reading is taught starting from third-grade of primary school.

The process of teaching beginning reading is not easy because there are still many students who are able to read, but still have difficulty learning to read. In addition, it is also caused by a less meaningful learning process for students. The use of innovative learning media is expected to help the learning process to be more meaningful. Students who have learning difficulties, media is needed to facilitate the learning process (Abdurrahman, 2012; Akyol, Cakiroglu, \& Kuruyer, 2014).

Gagne in Susilana \& Riyana (2008) and Arsyad (1997) explained that media are various types of components in a student environment that can stimulate students to learn. Learning media has a very important role in the learning process to deliver information provided by the teacher to students. Learning media should be used by teachers to facilitate their students in learning, especially learning to read.

Big Book media is one of the learning media that can be used by teachers to teach beginning reading.. This media can help students' recognizing the writing symbols. If students usually learn to read from smallsized books or teacher's notes on the board, the Big Book media can help students learn to read from large-sized books, and even interesting images in the books. Besides the size of the book that is larger than usual, the Big Book media also presents reading material with certain themes so that it facilitates students to understand the contents of their reading.

The big Book media can be used by students for the beginning reading learning. Since first-grade and second-grade primary school students are still in the stage of recognizing and pronouncing the letters, thus learning media are needed. Moreover, Big Book media contains large and varied images. First-grade and second-grade students usually like illustrated books, thus this media can help teachers to teach reading to their students.

Big Book learning media is expected to increase students' motivation to learn beginning reading. In 2015, the government collaborated with USAID (United States Agency for International Development) to improve the primary 
school students' reading ability. At the primary school level, USAID trained hundreds of teachers to design and make the Big Book. This program aims at bringing Indonesia education to the world. However, this program is unfortunately not evenly distributed in every region. There are some schools in each province participated in this program.

Students who have difficulties in the beginning reading can be introduced to the teacher with the Big Book learning media. This learning media is designed based on the needs and level of students' development. First-grade primary school students who are still in the concrete operational stage need a real learning media that can make the learning process more meaningful. This learning media is also needed by students because first-grade students in primary school require media or tools to stimulate and motivate them to learn reading.

\section{METHOD}

This study involved second-grade students in one of primary schools in Tasikmalaya City. In addition, this study employed a descriptive qualitative research method. The procedure in collecting qualitative research is data analysis, data interpretation, and writing reseach results (Creswell, 2014). A descriptive qualitative research was chosen to describe or explain the learning process using Big Book media at the beginning reading learning.

\section{Research Data Sources}

The data obtained in this study are as follows:

1. Classroom teachers

Classroom teachers are managers and leaders of teaching and learning activities in classroom. Therefore, the researchers really need data relating to research from classroom teachers who are involved as research subjects.

2. Students

Students are the subject of learning. Therefore, the researchers really need accurate information about the teaching and learning process in the classroom from all students.

3. Document

The document is a support in this study. The document used as a source of data by the researchers is the student learning outcomes

\section{Research Instruments}

This study employed descriptive qualitative method. The main instrument is the researchers themselves. Researchers try to see the problems objectively that occurred in the field. In addition, the instruments in this study were interview sheets and observation sheets, and documentation.

\section{Data Collection Technique}

The data was collected using a combination of strategies in collecting data to obtain valid and reliable data, so that the subjectivity of the researchers is 
Riga Zahara Nurani \& Hatma Heris Mahendra, Use Of Big Book Learning Media To Improve Students'...

considered as the main instrument of the research that can be avoided. Therefore, the data collection techniques are as follows:

1. Observation sheet

The observation sheet was used to examine the implementation of the beginning reading learning using the Big Book learning media in the classroom.

2. Interview sheet

Interview sheets are used to find out more in depth more information strengthening from the implementation of the beginning reading learning using the Big Book learning media in the classroom.

3. Documentation

Documentation is carried out by the researchers to support the sources studied. Documentation in the form of photographs, recordings, and assessment of other documents is needed to support research.

\section{Data Analysis Technique}

Data analysis in qualitative research was carried out before conducting the research, while conducting the research, and after conducting the research (Sugiyono, 2010). The data analysis conducted by the researchers is categorized into three sections, namely:

1. Analysis before conducting the research Data analysis before conducting the field is necessary to determine the focus of research. This analysis can be carried out through preliminary studies, or secondary data.

2. Analysis while conducting the research Data analysis while conducting the research is considered as the most important aspects in the research process. This data analysis is performed until the data is saturated. The steps in data analysis while conducting the research are as follows:

a. Data reduction

Data reduction is a sensitive thought process that requires high intelligence, breadth, and depth of insight. Data reduction was carried out by collecting data in the research site, both in the form of field notes, interviews, documentation of activities, etc. After collecting the data, the data were selected and categorized based on the needs of the researchers.

b. Presentation of data The presentation of the data was carried out to facilitate efforts to understand what is happening, and the further research plan. The subjectivity of the researchers should be avoided. Therefore, the research results can be obtain more credible and trusted.

c. Verification

As a conclusion, the data verification is carried after the data is collected and presented. 
3. Analysis after conducting the research Analysis after conducting the research is carried out by sorting and categorizing the data in accordance with their needs. In addition, triangulation was carried out so that the data collected was more convincing to be described.

\section{RESULTS}

The research on the use of Big Book media in the beginning reading learning was carried out for second-grade primary school students in the 2019/2020 school year. Based on the results of the preliminary study, there were some students who were still able to read fluently. However, classroom teachers recommend five students to be given treatment in this study. The students included in this study were students who had difficulties in reading learning, even though most of their classmates were already able to read fluently.

This study was divided into three stages of activity using three different Big Book media. The first stage is the introduction of vowels and consonants following simple words using the Big Book media called transportation equipment. The second stage is the introduction of words with multiple vowels and consonants using the Big Book media called the animal world. The third stage is the processing of simple sentences using the big book media called vegetables.

\section{First Stage of the Research}

The introduction of vowel and consonant letters was carried out in this stage. In the beginning, the teacher wrote letters $A$ to $Z$ on the board. The teacher mentioned each letter on the board, which was repeated by the students. This activity aimed at introduced students to the sound of the letters on the board. Most students already know the alphabet, although there were some letters that students forgot to read.

After introducing all the alphabetical letters, the teacher introduced the consonant and vowel letters. Teachers circled the vowel letters using red markers. The vowel letters consisted of $A, I, U, E$, and $O$. The teacher mentioned them several times, and the students repeated the vowel letters until they memorized them. The teacher emphasized that apart from these five letters, they were all consonant letters

Furthermore, the big book media was used by teachers to teach simple words. In the big book media entitled "Transportation", there are images and writings of kereta api (train), mobil (car), motor (motorcycle), kapal laut (ship), and helikopter (helicopter). To teach these words to the students, the teacher spelled "KERETA API" on the board and then asked students which vowel letters are in that word. The teacher circled letters $E, A$, and I in the word KERETA API.

Teachers broke down the letters in the word KERETA API into the consonant letters 
Riga Zahara Nurani \& Hatma Heris Mahendra, Use Of Big Book Learning Media To Improve Students'...

consisting of the letters $K, R, T$, and $P$. Then each consonant was added with the following five vowel letters.

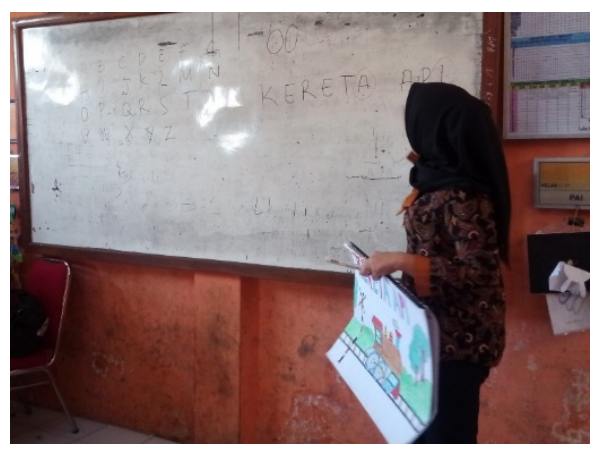

Figure 1. The Teacher Taught Vowel and Consonant Letters

Letter K: KA, KI, KU, KE, KO

Letter R: RA, RI, RU, RE, RO

Letter T: TA, TI, TU, TE, TO

Letter P: PA, PI, PU, PE, PO

The students were instructed by the teacher to randomly mention each of the letters. Each student had a turn to mention the combination of the vowel and consonant letters. Almost all students were able to read the letters fluently, even though they had to be repeated several times.

The series of consonants and vowels arranged by the teacher were combined to be a word that must be read by the students. The words taught by the teacher based on the combination of letters included KAKI, KARI, KOTA, KOPI, KUTU, ROTI, RAPI, RUPA, RATU, RATA, TARI, TAPI, TEKO, TOPI, TIPU, PARI, PATI, PITA, PORI, and PERI. The students took a turn to read the words compiled by the teacher. The following was the results of students' reading learning in the first stage.
Table 1. Result of Students' Reading Learning in the First Stage

\begin{tabular}{lcc}
\hline Type of Skills & Can & Cannot \\
\hline Read vowels & 5 & 0 \\
Read consonants & 5 & 0 \\
Read syllables & 4 & 1 \\
Read words & 3 & 2 \\
\hline
\end{tabular}

Table 1 presents that all the students had been able to read vowels and consonants in the first stage (100\%), while there were four students those who could read syllables (80\%) and three students who could read the word (60\%). In the next stage, the teacher taught about syllables with different levels of difficulties.

\section{Second Stage of the Research}

After introducing the consonant and vowel letters in this previous stage. In the beginning, the teacher wrote letters $A$ to $Z$ on the board. The teacher mentioned each letter on the board, and the students repeated them. This activity aimed at introducing the students to the sound of the letters on the board. Most students already knew the alphabet, there were only a few letters that students forgot to read.

At this point, students were taught to read syllables consisting of three or more letters with double vowel, double consonant, or a combination of vowels and consonants. Besides, students were also taught about the combination of letters ng and ny. The Big Book media used was entitled "Animal World". In this book, there were pictures and writings of gajah (elephant), harimau 
(tiger), monyet (monkey), kangguru (kangaroo), and musang (civet).

In teaching syllables consisting of three or more letters, the teachers used punctuation for every two letters in the word. Letters that do not have a pair should be spelled at the same time as the previous two letters. The following is an example of a syllabus spelling taught by a teacher.

$$
\begin{aligned}
& \text { GAJAH is spelled GA-JAH } \\
& \text { HARIMAU is spelled HA-RI-MAU } \\
& \text { BEBEK is spelled BE-BEK }
\end{aligned}
$$

However, this method could not be used when there was a double consonant in the middle. If there was a double consonant in the middle of the sentence, then the consonant must be separated. For example:

\section{MARMUT is spelled MAR-MUT \\ $\mathrm{KANCIL}$ is spelled $\mathrm{KAN}-\mathrm{CIL}$ \\ KERBAU is spelled KER-BAU}

After teaching syllables consisting of three letters, the teacher taught the concepts of ng and ny. At first, the students found difficulties in reading the words that contained the combination of letters $\mathrm{ng}$ and ny. However, the teacher gave an example of how to spell ng and ny repeatedly. When the students found the combination of letters $n g$, it is considered as one letter only, and the pronunciation followed the previous syllable. Meanwhile, for the combination of letters ny, the pronunciation followed the next syllable. The following is an example taught by the teachers.

\author{
KANGGURU is spelled KANG-GU-RU \\ MUSANG is spelled MU-SANG \\ KUCING is spelled KU-CING \\ MONYET is spelled MO-NYET \\ PENYU is spelled PE-NYU
}

At this stage, some students still had difficulties in pronouncing the words, because the students were used to finding words with syllables. However, along with the frequent meetings in the classroom, the students were able to certainly pronounce the combination of letters ng and ny fluently. The following was the results of students' reading learning in the second stage.

Table 2. Result of Students' Reading Learning in the Second Stage

\begin{tabular}{lcc}
\hline Type of Skills & Can & Cannot \\
\hline Spell three letter syllables & 4 & 1 \\
Spell ng & 3 & 2 \\
Spell ny & 3 & 2 \\
\hline
\end{tabular}

Table 2 shows that there were four students who were able to spell syllables consisting of three letters fluently (80\%). Meanwhile, there were two students who had not been fluent in the pronunciation of ng and ny, especially when the letters ng and ny are in the middle of the letters.

\section{Third Stage of the Research}

At this stage, the students were taught with simple sentences consisting of two-three words. The Big Book media used was entitled "Vegetables". This book contains pictures and writings of wortel (carrot), timun (cucumber), jamur (mushroom), 
Riga Zahara Nurani \& Hatma Heris Mahendra, Use Of Big Book Learning Media To Improve Students'...

brokoli (broccoli), and tomat (tomato). In general, the students were able to read well what taught by the teacher, because they had been taught to read the words before in the first and second stages, while at this stage, the students were evaluated what had been learned in the first and second stages.

Before teaching the concept of simple sentences, the teacher reminded the students to read one word contained in the big book.

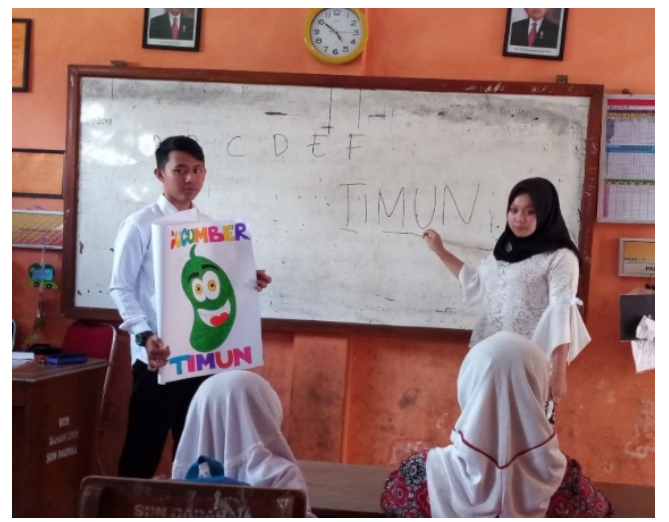

Figure 2. Third Stage of Learning Process

In reading simple sentences, almost all students were able to read them. The following are the sentences taught at the third stage.

INI WORTEL are read I-NI WOR-TEL

TIMUN BERWARNA HIJAU are read TI-MUN BER-WAR-NA HI-JAU

IBU MEMBELI JAMUR are read I-BU MEM-BELI JA-MUR

ANGGI MAKAN BROKOLI are read ANG-GI MA-KAN BRO-KO-LI

SONYA MAKAN TOMAT are read SO-NYA MA-KAN TO-MAT

However, there were some students who had difficulties in reading multiple consonants, multiple vowels, and words with the combination of letters ng and ny, for example, multiple consonants in BROKOLI, multiple vowels in HIJAU, combination of letters ng in ANGGI, combination of letters ny in SONYA. The following is the results of students' reading learning in the third stage.

Table 3. Result of Students' Reading Learning in the Third Stage

\begin{tabular}{lcc}
\hline Type of Skills & Can & Cannot \\
\hline Multiple consonants & 3 & 2 \\
Multiple vowels & 2 & 3 \\
Read ng & 3 & 2 \\
Read ny & 3 & 2 \\
\hline
\end{tabular}

Table 3 shows that there were three students who were able to read multiple consonants fluently, and two students who had not been able to read them fluently. On the other hand, there were two students who were able to read multiple vowels fluently, and three people who had not been fluent in reading multiple vowels. Meanwhile, there were three students who were able to read the letters ng and ny fluently, and two people who had not been able to read them fluently.

\section{DISCUSSION}

The use of big book media for the beginning reading learning can help the students who have difficulties in reading. In line with Earle \& Sayeski (2017), direct teaching involves the identification of the specific concept or skill taught and the teaching tools, Based on the results of three stages in this study, all the students were 
able to read vowels and consonants well. Likewise in reading syllables and words, there were $80 \%$ of the students who are able to read syllables and $60 \%$ of the students who are able to read words. Furthermore, in learning to read syllables consisting of three letters, there were $80 \%$ of the students who are able to read them fluently.

The most students had difficulties in learning to read when they found words with multiple consonants, multiple vowels, and letters ng and letters ny. In reading words and syllables that contain letters and ny, there were $60 \%$ of the students who were able to read them fluently. Likewise the students who were able to read multiple consonants. The research on student's ability in reading vocabulary also has been done by Aarnoutse, et all, (2001) that "for reading comprehension, the progress in grade 2 was lower than the progress in grade 3 , but progress was declining across higher grades".

The biggest difficulties experienced by students in the beginning reading learning was when they found multiple vowels. This could be seen from the number of students who were able to read multiple vowels with the percentage of $40 \%$. Misconception in reading are often discovered by the students who learn to read, especially in sound pronunciation (Earle \& Sayeski, 2017).

Even though, there are still students who have difficulties in the beginning reading, the use of this big book learning media can increase students' desires and motivation in learning to read. The use of media images can increase student motivation (Agustina, 2018; Kusdemir, 2018). This is because students learn not only through ordinary text books, but also through interesting books and images in the book. The selection of teaching strategies in reading is needed to improve student's understanding in reading (Braojos, Fernandez, \& Vilchez, 2014). By choosing appropriate learning strategies and media, students can feel that learning to read is more meaningful.

\section{CONCLUSION}

Learning to read in primary schools, especially in low classes, must be accompanied by the use of learning media. One of the media that can be used in the beginning reading learning is the big book media. This media is in the form of a large book containing certain themes, such as animals, plants, activities, and more.

The research results revealed that the use of big book media can improve students' ability to read in the beginning reading learning. This can be seen from the increasing ability of the students from day to day in the beginning reading learning. However, there are still some difficulties experienced by students in learning to read, such as difficulties in reading multiple vowels, multiple consonants, combinations of letters ng and letters ny. 
Riga Zahara Nurani \& Hatma Heris Mahendra, Use Of Big Book Learning Media To Improve Students'...

\section{ACKNOWLEDGMENTS}

This study was a grant from the Ristek-Dikti. The researchers would like to express my gratitude and appreciation to the RistekDikti for the support and assistance provided in the implementation of this study as one of the three pillars of higher education that must be carried out by lecturers. In addition, the researchers would also like to thanks the teachers, students, the principal of SDN Dadaha and other parties involved in this study.

\section{REFERENCES}

Aarnoutse, C., Leeuwe, J. V., Voeten, R., \& Oud, J. H. L. (2001). Development of decoding, reading comprehension, vocabulary and spelling during the elementary school year. Reading and Writing, 14(1), 61-89. DOI: 10.1023/A:1008128417862.

Abdurrahman, M. (2012). Anak Berkesulitan Belajar: Teori, Diagnosis, Dan Remediasinya. Jakarta: Rineka Cipta.

Abidin, Y. (2010). Strategi Membaca Teori dan Pembelajaran. Bandung: Rizqi Press.

Agustina, D. D. (2018). The Use of Double Match Picture Media For Teaching Reading Comprehension. Premise: Journal of English Education and Applied Linguistics, 7(2), 44-60. DOI: 10.24127/pj.v7i2.1570.

Akyol, H., Cakiroglu, A., \& Kuruyer, H. G. (2014). A Study on the Development of Reading Skills of the Students Having Difficulty in Reading: Enrichment Reading Program. International
Electronic Journal of Elementary Education, 6(2), 199-212.

Amutha, S. \& Philomina, M. J. (2015). Diagnosis of Reading and Writing Skills in Primary school Students. International Journal of English Language Teaching, 3(7), 1-7.

Arsyad, A. (1997). Media Pembelajaran. Jakarta: PT Raja Grafindo Persada.

Braojos, C. G., Fernandez, S. R. \& Vilchez, P. S. (2014). How Can Reading Comprehension Strategies and Recall Be Improved in Elementary School Students?. Estudios Sobre Educacion, $26,9-31$.

Creswell, J. W. (2014). Penelitian Kualitatif dan Desain Riset. Yogyakarta: Pustaka Pelajar.

Earle, G. A. \& Sayeski, K. L. (2017). Systematic Instruction in PhonemeGrapheme Correspondence for Students with Reading Disabilities. Intervention in School and Clinic, 52(5), 262-269.

DOI:

$10.1177 / 1053451216676798$.

Gilakjani, A. P. \& Sabouri, N. B. (2016). How Can Students Improve Their Reading Comprehension Skill. Journal of Studies in Education, 6(2), 229-240. DOI: 10.5296/jse.v6i2.9201.

Kusdemir, Y. \& Bulut, P. (2018). The Relationship between Elementary School Students' Reading Comprehension and Reading Motivation. Journal of Education and Training Studies, 6(12), 97-110. DOI: 10.11114/jets.v6i12.3595. 
Rahim, F. (2008). Pengajaran Membaca di Sekolah Dasar. Jakarta: Bumi Aksara.

Sugiyono. (2010). Metode Penelitian Pendidikan (Pendekatan Kuantitatif, Kualitatif, dan R\&D). Bandung: Alfabeta.

Susilana, R. \& Riyana, C. (2008). Media Pembelajaran (Hakikat, Pengembangan, Pemanfaatan, dan Penilaian). Bandung: Jurusan Kurikulum dan Teknologi Pendidikan FIP Universitas Pendidikan Indonesia.

Stewart, J. H. (2005). Foreign Language Study in Elementary Schools: Benefits and Implications for Achievement in Reading and Math. Early Childhood Education, 33(1), 11-16. DOI: 10.1007/s10643-005-0015-5.

Tarigan, H. G. (2008). Membaca Sebagai Suatu Keterampilan Berbahasa. Bandung: Angkasa. 